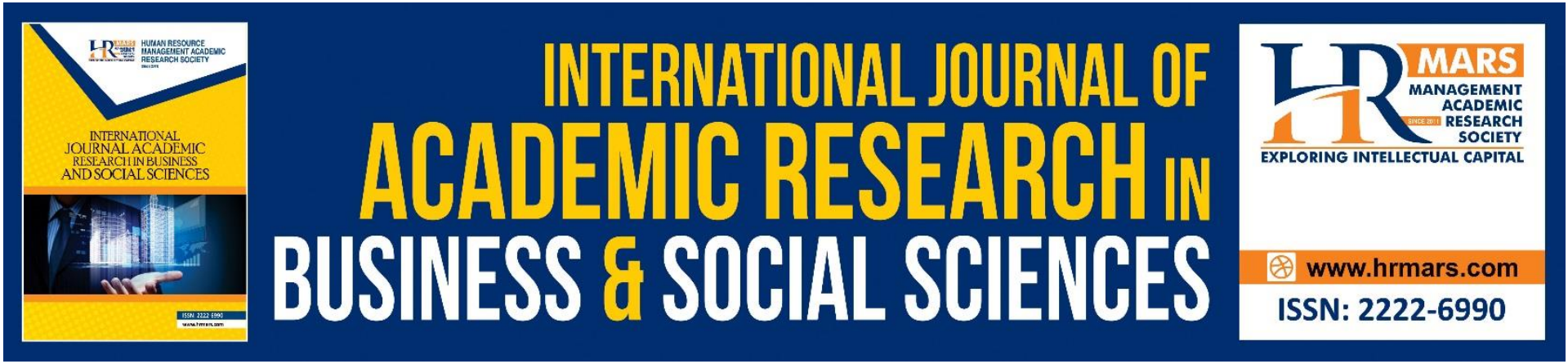

\title{
Exploring the Determinants for Strengthening the Training Quality for Mathematics Teachers in Oman
}

Sultan Saqar Alwahaibi, Johanim Johari

To Link this Article: http://dx.doi.org/10.6007/IJARBSS/v11-i12/11569

DOI:10.6007/IJARBSS/v11-i12/11569

Received: 12 October 2021, Revised: 15 November 2021, Accepted: 30 November 2021

Published Online: 17 December 2021

In-Text Citation: (Alwahaibi \& Johari, 2021)

To Cite this Article: Alwahaibi, S. S., \& Johari, J. (2021). Exploring the Determinants for Strengthening the Training Quality for Mathematics Teachers in Oman. International Journal of Academic Research in Business and Social Sciences, 11(12), 696-708.

Copyright: @ 2021 The Author(s)

Published by Human Resource Management Academic Research Society (www.hrmars.com)

This article is published under the Creative Commons Attribution (CC BY 4.0) license. Anyone may reproduce, distribute, translate and create derivative works of this article (for both commercial and non0-commercial purposes), subject to full attribution to the original publication and authors. The full terms of this license may be seen at: http://creativecommons.org/licences/by/4.0/legalcode

Vol. 11, No. 12, 2021, Pg. $696-708$

Full Terms \& Conditions of access and use can be found at http://hrmars.com/index.php/pages/detail/publication-ethics 


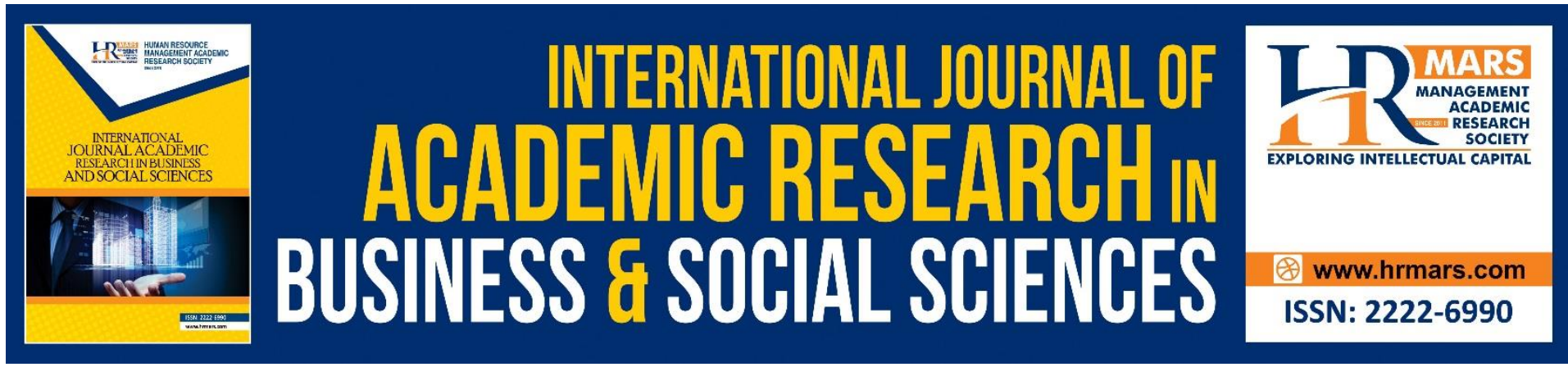

\title{
Exploring the Determinants for Strengthening the Training Quality for Mathematics Teachers in Oman
}

\author{
Sultan Saqar Alwahaibi, Johanim Johari \\ Doctor of Business Administration Student at Othman Yeop Abdullah Graduate School of \\ Business, Universiti Utara Malaysia, Sintok-Kedah, Malaysia 1; School of Business \\ Management, College of Business, Universiti Utara Malaysia, Sintok, Malaysia 2. \\ Email: sultan_saqar@oyagsb.uum.edu.my, johanim@uum.edu.my
}

\begin{abstract}
Keeping in view the research objective "To determine the strengths of mathematics teachers training in SIPTT from trainees' perspective" current research attempted to explore the factors affecting the training quality and become a point of strength for mathematics teachers training in SIPTT. For achieving this purpose, recent research focused to conduct interviews. In total 12 online interviews were conducted due to the strictness of covid-19 regulations. The current research used a single instrumental qualitative case study to gather extensive data from trainees' perceptions to understand poor training results and withdrawal. Based on the interview data current research explored Context, Administration, Input, Process, and Output) factors as strengthening points for training qualities. Current research possesses remarkable implications and contributions towards the quality of mathematic teachers in Oman.
\end{abstract}

Keywords: Training Quality, CAIPO Training Evaluation, SIPTT, Oman.

\section{Introduction}

Training of employees is essential for organizational effectiveness. Through training, employee skills and knowledge can be updated and enhanced, contributing to the sustainability of the organization. In the context of educational institutions in the Sultanate of Oman, educational training is needed to develop teachers' knowledge, skills, and abilities (Al-Jabri et al., 2018). One of the key institutes that provide training programs to teachers in the country is the Specialized Institute for Professional Training of Teachers (SIPTT), which was established in 2014 in alignment with the Omani Vision 2020 (MOE, 2014).

Notably, the SIPTT's role is also to develop some comprehensive mechanisms and plans for training and monitoring teachers' performances in education (Al-Jabri et al., 2018). Fundamentally, these training programs aim to improve the teachers' confidence, motivation, and skills to a level that meets the highest standards so that student learning outcomes are enhanced (MOE, 2014). Evidence shows that an effective training program facilitates the improvement of organizational deficiencies (Shenge, 2014). The SIPTT supports trainees 
through ongoing communication with the SIPTT trainers and the provision of technical support and feedback through the e-learning platform, regional visits, and provision of a tablet computer for e-learning. To support workplace learning, the MOE provides pre-paid internet services. To complete their learning activities, trainees are not required to attend their schools on the study day. Management support is a critical issue in the transfer of learning at the workplace.

SIPTT offers a two-year mathematics voluntary diploma training program to mathematics teachers to improve the mathematics education learning outcome in Oman. The objective of this program is to enhance the teachers' learning and teaching capabilities so that they could be groomed as program leaders in mathematics. The SIPTT mathematics teachers training program is voluntary and targeted at mathematics teachers in grades 5-10. The mathematics teachers training program delivers to investigative learning techniques, research methods, and the implementation of mathematical concepts. Despite being voluntary, participant recruitment targets are based on the strategic model of SIPTT. The mathematics teachers training is a blended program where each module contains three components: (a) 22.5 hours of face-to-face training in five days (30\%), (b) online training (20\%), and (c) workplace task application (50\%). Each training module is evaluated by submitting an achievement file that contains samples of the teacher's work and a comprehensive report on all unit elements.

Despite the resources expended toward the mathematics training programs offered by MOE and organized by SIPTT, the program appears to be ineffective in meeting the objectives. The success rate of mathematics teacher trainees attending the SIPPT mathematics programs is the lowest compared to other trainees in other SIPTT programs since its establishment in 2014 (SIPTT, 2021).

As compared to other training programmes at the SIPTT, mathematics teachers have lowest scores in two cohorts. Beside this there was huge withdrawal from training cohorts, this withdrawal was on increasing trend (SIPTT, 2021). This withdrawal has been noticed as serious issue. Perhaps there are many factors those affect towards the withdrawal, low score has raised a key question on quality of training program offered by SIPTT.

One of the critical concerns in training is the quality so that the possibility of change exists (Rajasekar \& Khan, 2013). According to Beardwell and Thompson (2017), training quality is a critical factor in achieving an organization's strategy. Enhancing the quality of training practices by practitioners is a possibly reliable driver of beneficial change (McChesney \& Aldridge, 2018). However, frequently, organizations fail to determine the quality of their training programs despite the high spending on training every year (Singh et al., 2015). Past studies on teacher professional development programs reported disappointing results in terms of the quality to help teachers improve teaching practices and even more disappointing results in terms of their effect on learning and achievement of students (Cave \& Brown, 2010; Desimone \& Garet, 2015; Garet et al., 2011; Lipowsky \& Rzejak, 2015; Yoon et al., 2007).

However, there is little evidence indicating that the training programmes by SIPTT have achieved the desired result in enhancing the performance of the mathematics teacher trainees. Hence, it is critical that a study be conducted to address the issue of training quality offered by the SIPTT. 
Studies on training evaluation revealed that most Gulf countries, including Oman, have difficulty evaluating training (Al-Mughairi, 2018). In Oman, this occurs despite spending approximately USD156 million on the development activities in the MOE, including training programs (MOE, 2018). One of the reasons could be several crucial discrepancies between theoretical conceptualizations and empirical operationalization of training criteria that have hindered advancement in training evaluation (Sitzmann \& Weinhardt, 2019). Moreover, the training evaluation processes in Oman are simply done to see trainees' reactions to the programs without centering on the quality of the training program in attaining the projected goals (Al-Nabhani, 2007). Overall, the information on the training quality has been scant regardless of the substantial utilization of resources in-service teacher training programs (Arancibia, Evans, \& Popova, 2016), and it is often reported that most recent teacher training programs are over-theoretical and outdated (Loyalka et al., 2018).

Although many studies have been done on training evaluation in Oman (Alaraimi \& Othman, 2015; AlBalushi, 2018; Al-Hosni, 2014; Al-Jabri et al., 2018; Al-mughairi, 2018; AlOmrani, 2014; Alshykairi, 2020; SIPTT, 2020; Rajasekar \& Khan, 2013), little academic attention is given to trainees' perceptions of non-mandatory mathematics teacher training program. This is perhaps because most mathematics teachers training programs in Gulf countries are not subject to any type of evaluating training quality (Alamri et al., 2018), resulting in scare research works. Therefore, the present study attempts to investigate mathematics trainees' perceptions about the quality of mathematics teachers training programme of the SIPTT by using a qualitative approach guided by the ContextAdministration-Input-Process-Outcome (CAIPO) training evaluation model to get a comprehensive and in-depth understanding of the issue. Keeping in view the importance of highlighted issue, current research is based on the objective and research question as;

\section{Research Objective}

To determine the strengths of mathematics teachers training in SIPTT from trainees' perspective.

\section{Research Question}

What key indicators do trainees perceive as being the strengths of the mathematics teachers training programme in SIPTT? 


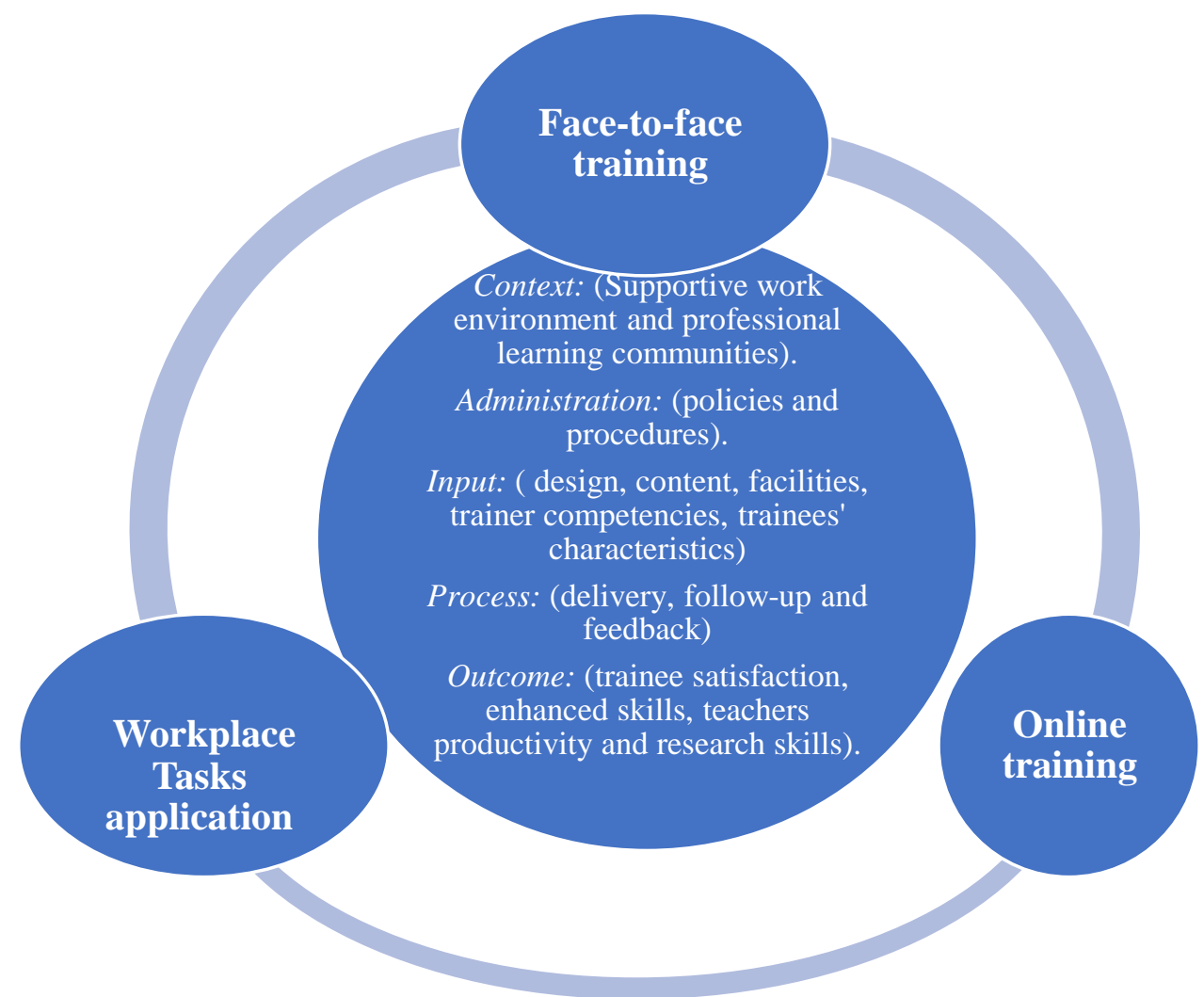

Figure 1.2 Frame work of the research

\section{Material and Method}

\section{Research Approach}

Considering the nature of the current study and stated objectives, "holistic case study with multiple cases" was appropriate and therefore followed. Dyer \& Wilkins (1991) argued that holistic (or single) case study designs are essential because this allows a deep contextualized understanding of the case. In the present study, a multiple case study was considered as an appropriate in which the context was "Mathematics teachers training at the SIPTT". The case of the mathematics trainings provides deeper insight into an issue needing refinement, knowing the strengths of mathematics teachers training to enhance training quality.

This study adopted a single instrumental qualitative case study to gather extensive data from trainees' perceptions to understand poor training results and withdrawal. The investigation provides insight into an issue needing refinement (knowing the strengths of mathematics teachers training) to enrich training quality. Mathematics teachers training at the SIPTT is carried on continuously, so it is not an intrinsic case.

\section{Study Design and Setting}

Exploratory qualitative research under the case study approach was considered appropriate to explore the main objectives of the present research. The case study approach provided a detail picture of programme operations, often at some locations, resulting in a deeper understanding of how and why programme operations relate to outcomes (Newcomer et al., 2015). Qualitative research does not consider on generalizability rather every case had its own experience and viewpoint which helps to identify the real facts of the 
research (Mayring, 2007). The overall objective of this research was to disclose the key indicators of the quality of mathematics teachers training.

\section{Data Collection and Procedures}

The primary data for this research was gathered through the online interviews. Before starting the formal process of interviews, each participant was contacted through researcher for seeking permission. Ten online interviews were conducted through the zoom session. Due to some technical issue with Zoom, two telephone interviews had to be used. After twelve interviews, the saturation point came where researcher stopped interviews (seven participants who passed the training, three who withdrew, and two who failed). Notably, most data were obtained from those who passed the programme. The size of 12 participants in this study was consistent with Guest, Bunce, and Johnson (2006), who found that saturation occurred within the first twelve interviews. Additionally, Kuzel (1992) tied his recommendations to a sample of twelve to twenty data sources "when looking for disconfirming evidence or trying to achieve maximum variation" (p. 41).

To achieve this, current research followed the list of trainees in the first and second cohorts accessible at the SIPTT to recruit the participants who met the criteria. Obtaining the list was possible because the researcher is employed there. The trainees were then classified based on their results in the program (passed, failed, and withdrew). The maximal variation strategy was considered in each group. For achieving desired sample size current research used nonprobability purposeful sampling approach was chosen because it was more suitable than theoretical sampling to understand the participants' views regarding the quality of mathematics training. The present study employed the maximal variation sampling strategy to get multiple perspectives about the phenomenon from the participants who differ in some characteristics (Creswell \& Poth, 2018), besides enhancing transferability (Merriam \& Tisdell, 2015). The logic for using this sampling strategy was to choose mathematics trainees that represented a unique mixture of demographic features. The present study chose the interview technique to investigate the participants' perspectives on mathematics teachers' training quality at SIPTT.

An interview protocol was developed to guide the data collection process during the interview (Creswell \& Poth, 2018). The initial interview protocol involved six questions, as follows: (1) why did you participate in this program? (2) Do you think the training program has fulfilled your training needs? Why or why not? (3) What was the biggest takeaway of this program for you? Why? (4) Did you face challenges in the program? Why? (5) Do you think the program should be improved? If yes, in what ways? What aspects of it needs improvement? If no, are you happy with all aspects discussed throughout the program? How? (6) Is there any comments relevant to what has been discussed before we end our meeting? Before the actual data collection, written permission to conduct the study was sought from the MOE in Oman. The letter stated the purpose of the current research, the participants, and the type of data to be collected. Due to the coronavirus pandemic and the government restriction, the researcher could not conduct a focus group as planned. Instead, the researcher had to conduct an online interview via Zoom. Before the online interview could be performed, the researcher set up an online appointment to find each participant's best and most convenient time by using phone calls or WhatsApp. The interviews were done in Arabic to ensure comfort in eliciting views and opinions. 


\section{Analyses}

The current study, the collected data were analyzed according to the research questions. Nevertheless, the process of analyzing and interpreting data was continuous, as this research discovered new information every now and then. For this reason, the current study followed closely, if not all, the seven-step analysis procedure suggested by Adu (2019): Every interview was analyzed for "internal consistency" to assess dependability (Thompson, 2000 , p. 272) to allow the researcher to determine if individuals truly remembered or just reflecting on their previous mathematics teachers training experiences. The technique of coding followed by arranging the ideas generated into themes representing the interviewees' responses. Codes were further analyzed to form themes. Each theme represented a broad, meaningful idea representing the participants' point of view conceived from coding analysis (Creswell, 2013). Lastly, the themes were organized for interpretation using simple frequency analysis.

\section{Results}

\section{Participants}

Twelve participants from three groups (those who passed, failed, and withdrew) were interviewed in this study. Of 12 participants, 58.3\% were between 35 and 38 years old, while $41.6 \%$ were between 41 and 44 years old. On teaching experience, $58.3 \%$ had teaching experience between 12 and 15 years, while $41.6 \%$ had between 17 and 20 years of experience. Since the programme was not mandatory, one of the criteria for selecting a candidate is that he/she should have teaching experience of five years or more. In terms of gender, $25 \%$ of participants were women, and $75 \%$ were men. Many more men were in the second cohort than women. Only a quarter of them was from the first cohort, while $75 \%$ were from the second cohort. More took part in the second cohort because much time had passed since the first batch was taken in 2014. Also, during the pilot study, the researcher found that some trainees who attended in the first cohort had changed their job titles.

Participants were from seven different educational governorates over the country. In terms of trainee results, $58.3 \%$ passed the program, $25 \%$ withdrew from the programme, and $16.6 \%$ failed the programme. Those who passed had a comprehensive overview of the program.

\section{Findings}

Five elements (based on the CAIPO model) were thematically developed from the literature to be used as a lens to investigate the participants' perceived quality of a mathematics teachers training at SIPTT. The elements were context (work environment), administration (policies and procedures), inputs (training design, content, facilities, trainer competencies, trainee characteristics), process (trainer's delivery, follow-up, and feedback), and outcomes (perceived benefits).

\section{Context}

One concern developed from the literature is how the work environment influences the perceived quality of mathematics teachers training. The findings indicate that the work environment seems to affect the perceived quality of the training programme. The present study also reveals an emergent theme of professional learning communities in influencing perceived quality. 
The present findings highlight two primary areas of support influencing the first attendance in the training programme identified by the participants. They were the principal support and peer support. The findings are consistent with the importance of workplace support in motivating training participation (Matsumura et al., 2010).

\section{Administration}

According to the CAIPO model, such administrative issues could influence training quality. The study findings showed that most of the challenges facing the trainees in the program were concentrated in administrative aspects.

\section{Input}

The interviews showed that the sub-themes under the training input include training design, content, facilities, trainer competencies, and trainee characteristics. The present study revealed many factors surrounding the pre-training attitude (e.g., participants' expectations and their motivation to learn). Additionally, delivery, outcomes during and posttraining attitude, and learning style seemed to play a role in the participants' perception of training quality. Since the participants seemed to be of the same age group, experience, and educational environment, they held a similar opinion about the training quality. Unsurprisingly, the participants' high expectations for what the course would contain or eventually provide seemed to impact their perception of training quality. This has significant implications for assessing the quality of mathematics teacher training programs. If each participant has only hazy expectations from the course that are unrelated to the learning goals set by the course designer, assessing whether these outcomes were reached is useless.

\section{Process}

Process keeps track of the steps of training implementation. It serves as a continuous check on the execution of the training. From the participants' perspective, evaluating the quality of mathematics teachers training process revealed two sub-themes: training delivery and trainer follow-up and feedback.

\section{Outcomes}

The interviewees stated a large number of positive results of the training programme. Expectedly, this theme took the largest part of the strengths of the training programme, unlike other themes. Many benefits mentioned by the trainees reflected the quality elements in the programme. From the interviews, four sub-themes were extracted (a) trainee satisfaction, (b) enhanced skills, (c) teacher productivity, and (d) research skills.

\section{Discussion and Concluding Remarks}

This section gives an overview of the key findings based on the interviews conducted with the participants of the mathematics teacher training at the SIPTT. As detailed and discussed in the previous section, the key findings of the research provide a conceptual understanding and practical suggestions on mathematics teacher recruitment and their nonmandatory training in Oman generally and in the SIPTT context in particular. The study findings showed that participants hold different perspectives about the mathematics teachers' training quality at SIPTT. Based on the CAIPO model, the findings are summarized and organized into five themes: (a) context, (b) administration, (c) input, (d) process, and (e) 
output/outcome. In each theme, the strengths associated with the quality of the training program are identified.

Firstly, the context theme contains two sub-themes (school environment and professional learning communities) as the key indicators of the quality of mathematics teachers training. The interviewees valued the compatibility of the mathematics teachers training program offered by the SIPTT with their training needs to develop their teaching skills in the school environment. Additionally, the school principals were found to play an indirect role in enhancing the quality of the training program as they were supportive of the trainees attending the training program. The literature highlights that peer support encourages trainees to apply the new skills and transfer the training (Bhatti et al., 2013; Blanchard \& Thacker, 2013; Martins et al., 2019). Through peer support and encouragement, the interviewees indicated that the program had helped them engage with the professional learning community, another indication of the quality aspects of the training program.

The administration theme consists of the sub-themes of policies and procedures. The study results showed that the administrative aspects related to the training program focus on two components: the administrative circular to the schools and one-day release from the school. Both components were perceived to constitute the key strengths and hence quality of the training program as these policies encouraged and motivated them to attend. Administrative policies at all levels strongly influence training quality (Loucks-Horsley et al., 2010).

The input quality indicators of mathematics teachers training that emerged were related to training design, content, facilities, trainer competencies, and trainee characteristics. This study also found that the content and materials used in the mathematics teachers training were critical quality indicators. The trainers were also perceived to be qualified, knowledgeable, and specialized, indicating the quality of this specific training. The present study also revealed the role of trainee characteristics in training quality. It is contended that exploring this human aspect of assessment is easier to achieve when having the individual at the heart of a qualitative training evaluation. This finding broadly supports the work of other studies in this area linking trainee characteristics with training quality (Holton, 2005; Newcomer et al., 2015; Tai, 2006; Velada \& Caetano, 2007). The present results are significant in three major respects: readiness (Mavin et al., 2010; Williams, 2008), motivation (Omar et al., 2009; Tai, 2006; Yanson \& Johnson, 2016; Yaqoot et al., 2017), and self-efficacy (Yanson \& Johnson, 2016).

The quality indicators of mathematics teachers training at the process stage comprises training delivery and trainer follow-up and feedback. While both dimensions indicated quality, the feedback and follow-up were particularly significant to the trainees, especially in the workplace task applications component. SIPTT intentionally designed the program to constitute $50 \%$ of the feedback and follow-up component to apply and transfer their new skills at work effectively. This component was also found to be an important factor that encouraged trainees to take up voluntary training in subsequent modules.

The most apparent finding to emerge from the interviews is the outcomes of the training as one of the quality indicators. Outcomes reflect trainee satisfaction, enhanced 
skills, teacher productivity, and research skills obtained from training. Despite the poor performance of the first and second cohorts, all interviewees (those who passed, failed, or withdrew) stressed that the obvious significant outcomes were the updating of teaching practices and the use of technology in teaching mathematics. In general, they indicated that their performance had improved compared to those who did not attend the training. The improvement of the trainee's performance in the workplace is one of the quality indicators of the program (Harris \& Sass, 2011; Oguntimehin, 2005).

\section{Theoretical Implications}

The focus of this study was to gain an in-depth understanding of the factors influencing the quality of mathematics teacher training in the SIPTT in Oman by considering the environmental difference between the training centre in the SIPTT and trainees' schools. Therefore, this study looked at the quality of voluntary mathematics teacher training in SIPTT to fill the gap in the Oman context. Essentially, this research further contributes to the existing body of knowledge by investigating the effectiveness of voluntary training programmes (Huang et al., 2014; Gelkopf et al., 2008; Meier et al., 2012).

\section{Practical Implications}

Although each training quality factor had been studied individually, previous comprehensive investigation has been studied (face-to-face training, online training, and workplace tasks application) (Figure 1.2 frame work of the research) combined as one training program and relative contribution to training quality in a natural setting. This adds new insights into the actual training practices in the SIPTT instead of focusing only on the impact of the SIPTT training programs. The study findings will aid in comprehending participants' perceptions of the perceived quality of mathematics teacher training courses, resulting in a more precise alignment of provision with the needs of individual attendees. Further, training coordinators have been classified as a stakeholder that encompasses those individuals inside the MOE in Oman involved in the licensing, procurement, and administration of training. Typically, their role inside an establishment is to organize the SIPTT training program that meet both teachers and MOE objectives for professional career growth and increased operational efficiency. The outcomes of this study can benefit SIPTT training coordinators in two ways: first, by knowing participant views of program quality to design provision that is more aligned with needs and improving the SIPTT's initiatives to market and promote voluntary training courses within MOE in Oman.

\section{Conclusion}

Hence based on the findings, current study has achieved its objective and answered the research question regarding identification of key factors (Context, Administration, Input, Process, and Outcomes) to strengthen the mathematic teachers training program through SIPTT. This study looked at the quality of voluntary mathematics teacher training in SIPTT to fill the gap in the Oman context. Practically, this study adds new insights into the actual training practices in the SIPTT instead of focusing only on the impact of the SIPTT training programmes. 


\section{References}

Adu, P. (2019). A step-by-step guide to qualitative data coding. New York: Routledge.

Alamri, N. M., Aldahmash, A. H., \& Alsharif, K. M. (2018). Emerging trends in research on math teacher professional development. International Journal of Instruction,11(3), 91-106. doi: 10.12973/iji.2018.1137a

Alaraimi, A, S., \& Othman, A. (2015). Perceptions of educational managers about the effectiveness of selected training programmes: a case study in the Ministry of Education, Oman. IIUM Journal of Educational Studies, 3(2), 40-74.

AlBalushi, K. (2018). EFL teachers' CPD experience: Prespective from Oman. International Journal of Advanced Research, 6(5), 1345-1358.

Al-Hosni, Z. A. K. (2014). Training program evaluation for educational supervisors: Selected training programs in the headquarters of the ministry of education, sultanate of Oman (Doctoral dissertation, University of Malaya). Retrieved from http://studentsrepo.um.edu.my/4709/1/Zayid_Ali_-_Oman.pdf

Al-Jabri, M., Silvennoinen, H., \& Griffiths, D. (2018). Teachers' professional development in Oman: Challenges, efforts and solutions. International Journal of Learning, Teaching and Educational Research, 17(5), 82-103.

Al-Mughairi, A. M. (2018). The evaluation of training and development of employees: The case of a national oil and gas industry (Doctoral dissertation, Brunel University London).

Al-Nabhani, M. B. M. (2007). Developing the education system in the Sultanate of Oman through implementing total quality management: The Ministry of Education Central Headquarters: A case study. (Doctoral dissertation, University of Glasgow, UK).

Al-Omrani, K. A. (2014). Designing an effective training process a case study at Sohar Development Office Sultanate of Oman (Doctoral dissertation, Universiti Utara Malaysia, Malaysia).

Alshykairi, M., A. (2020). Evaluation of educational supervisors training program at the Specialised Institute for Professional Training of Teachers in Oman: Based on Stufflebeam Model. (Unpublished Master Thesis, Sultan Qaboos university, Oman).

Arancibia, V., Evans, D., \& Popova, A. (2016). Training teachers on the job: What works and how to measure it. World Bank Policy Research working paper, (7834).

Beardwell, J., \& Thompson, A. (2017). Human Resources Management: A contemporary approach (8th ed.). Essex, UK: Pearson Education Limited.

Bhatti, M. A., Battour, M. M., Sundram, V. P. K., \& Othman, A. A. (2013). Transfer of training: does it truly happen? European Journal of Training and Development,37(3), 273-297. doi: 10.1108/03090591311312741

Blanchard, N., \& Thacker.J. (2013). Effective Training: Systems, Strategies and Practices ( $5^{\text {th }}$ ed.) Pearson Education. Edinburgh Gate Harlow.

Cave, A., \& Brown, C. W. (2010, June). When Learning is at Stake: Exploration of the Role of Teacher Training and Professional Development Schools on Elementary Students' Math Achievement. In National Forum of Teacher Education Journal (Vol. 20, No. 3).

Creswell, J. W. (2013). Qualitative inquiry and research design: Choosing among five approaches ( $3^{\text {rd }}$ ed.). Thousand Oaks, California: Sage publications.

Creswell, J. W., \& Poth, C. N. (2018). Qualitative inquiry and research design: Choosing among five approaches ( $4^{\text {th }}$ ed.). Thousand oaks, California: Sage publications.

Desimone, L. M., \& Garet, M. S. (2015). Best practices in teachers' professional development in the United States. Psychology, Society and Education, 7(3), 252-263. 
Dyer Jr, W. G., \& Wilkins, A. L. (1991). Better stories, not better constructs, to generate better theory: A rejoinder to Eisenhardt. Academy of management review, 16(3), 613-619.

Garet, M. S., Wayne, A. J., Stancavage, F., Taylor, J., Eaton, M., Walters, K., ... \& Doolittle, F. (2011). Middle School Mathematics Professional Development Impact Study: Findings after the Second Year of Implementation. NCEE 2011-4024. National Center for Education Evaluation and Regional Assistance.

Gelkopf, M., Ryan, P., Cotton, S., \& Berger, R. (2008). The impact of a "training of the trainers" course for helping tsunami-survivor children on Sri Lankan disaster volunteer workers. International Journal of Stress Management, 15, 117-135.

Guest, G., Bunce, A., \& Johnson, L. (2006). How many interviews are enough? An experiment with data saturation and variability. Field methods, 18(1), 59-82. doi: $10.1177 / 1525822 \times 05279903$

Harris, D. N., \& Sass, T. R. (2011). Teacher training, teacher quality and student achievement. Journal of public economics, 95(7-8), 798-812.

Holton, E. F. (2005). Holton's Evaluation Model: New Evidence and Construct Elaborations. Advances in Developing Human Resources, 7(1), 37-54.

Huang, Y., Strawderman, L., Babski-Reeves, K., Ahmed, S., \& Salehi, A. (2014). Training effectiveness and trainee performance in a voluntary training program: Are trainees really motivated?. Nonprofit and Voluntary Sector Quarterly, 43(6), 1095-1110.

Kuzel, A. J. (1992). Sampling in qualitative inquiry. In B. F. Crabtree \& W. L. Miller (Eds.), Doing qualitative research (pp. 31-44). Newbury Park, CA: Sage Publications.

Lipowsky, F., \& Rzejak, D. (2015). Key features of effective professional development programmes for teachers. Ricercazione, 7(2), 27-51.

Loucks-Horsley, S., Stiles, K. E., Mundry, S., Love, N., \& Hewson, P. W. (2010). Designing professional development for teachers of science and mathematics ( $3^{\text {rd }}$ Ed.). Thousand Oaks, California: Corwin Press.

Martins, L. B., Zerbini, T., \& Medina, F. J. (2019). Impact of online training on behavioral transfer and job performance in a large organization. Journal of Work and Organizational Psychology, 35(1), 27-37. doi:10.5093/jwop2019a4

Matsumura, L. C., Garnier, H. E., \& Resnick, L. B. (2010). Implementing Literacy Coaching. Educational Evaluation and Policy Analysis, 32(2), 249-272. doi: 10.3102/0162373710363743

Mavin, S., Lee, L., \& Robson, F. (2010). The evaluation of learning and development in the workplace: A review of the literature. Higher Education Funding Council for England. London.

Mayring, P. (2007, September). On generalization in qualitatively oriented research. In Forum Qualitative Sozialforschung/Forum: Qualitative Social Research,8(3).

McChesney, K., \& Aldridge, J. M. (2018). A review of practitioner-led evaluation of teacher professional development. Professional Development in Education, 45(2), 307-324. DOI: $10.1080 / 19415257.2018 .1452782$.

Meier, A., Singletary, L., \& Hill, G. (2012). Measuring the impact of a volunteer-based community-development program in developing volunteers' leadership skills. Journal of Extension, 50(2), 1-10.

Merriam, S. B., \& Tisdell, E. J. (2015). Qualitative research: A guide to design and implementation ( $4^{\text {th }}$ ed.). San Francisco, CA: John Wiley \& Sons. 
Ministry of Education. (2014). The Specialised Institute for Professional Training of Teachers. $\left(2^{\text {nd }} \quad\right.$ ed.). Muscat: SIPTT. http://havasapps.com/test/moe/wpcontent/uploads/2016/07/TT_Information_E.pdf

Ministry of Education. (2018). The annual statistical indicators. Muscat: Author.

Newcomer, K. E., Hatry, H. P., \& Wholey, J. S. (Eds.). (2015). Handbook of practical program evaluation ( $4^{\text {th }}$ ed.). Hoboken, NJ: John Wiley \& Sons.

Oguntimehin, A. (2005). Teacher effectiveness: Some practical strategies for successful implementation of universal basic education in Nigeria. African journal of educational management, 9(1), 151-161.

Omar, S.S., Arokiasamy, L., \& Ismail, M. (2009). The Background and Challenges Faced by the Small Medium Enterprises. A Human Resource Development Perspective, International Journal of Business and Management, 4 (10), 95- 102.

Rajasekar, J., \& Khan, S. A. (2013). Training and development function in Omani public sector organizations: A critical evaluation. Journal of Applied Business and Economics, 14(2), 37-52.

Shenge, N. A. (2014). Training evaluation: process, benefits, and issues. IFE PsychologIA: An International Journal, 22(1), 50-58.

Singh, V. L., Manrai, A. K., \& Manrai, L. A. (2015). Sales training: A state of the art and contemporary review. Journal of Economics, Finance and Administrative Science, 20(38), 54-71.

Sitzmann, T., \& Weinhardt, J. M. (2019). Approaching evaluation from a multilevel perspective: A comprehensive analysis of the indicators of training effectiveness. Human Resource Management Review, 29, 253-269. doi: 10.1016/j.hrmr.2017.04.001.

Specilised Institute for Professional Training of Teachers. (2020). Measuring the impact of the training programs at SIPTT. [Unpublished]. Evaluation department: Author.

Specilised Institute for Professional Training of Teachers. (2021). (Training evaluation database). Unpublished raw data.

Tai, W. T. (2006). Effects of training framing, general self-efficacy and training motivation on trainees' training effectiveness. Personnel Review, 35(1), 51-65. DOI 10.1108/00483480610636786

Thompson, P. (2000). The Voice of the Past (3rd ed.). Oxford: Oxford University Press.

Velada, R., \& Caetano, A. (2007). Training transfer: the mediating role of perception of learning. Journal of European Industrial Training, 31(4), 283- 296 . doi: 10.1108/03090590710746441

Yanson, R., \& Johnson, R. D. (2016). An empirical examination of e-learning design: The role of trainee socialization and complexity in short term training. Computers and Education, 101, 43-54. doi: 10.1016/j.compedu.2016.05.010.

Yaqoot, E. S., Wan Mohd Noor, W. S., \& Mohd Isa, M. F. (2017). Factors influencing training effectiveness: Evidence from public sector in Bahrain. Acta Universitatis Danubius. CEconomica, 13(2), 31-44.

Yoon, K., Duncan, T., Lee, S., Scarloss, B., \& Shapley, K. (2007). Reviewing the evidence on how teacher professional development affects student achievement. Regional Educational Laboratory, 33, 1-55. 